\title{
Chapter 9 \\ The Migrating Poor: Romanian Roma Under Social Authoritarianism in Poland
}

\author{
Joanna Kostka
}

This chapter critically examines the discourse on "Roma exclusion" in the context of European migration policy, presenting key findings from the case study of Romanian Roma migrants in a city of Wroclaw in Poland. The concept of "Roma exclusion" has come to dominate political discussions about the marginalization of the largest European minority. Placed at the centre of the European Union political agenda it recognized that Roma poverty has multiple and interrelated causes, which require multifaceted policy responses. Nevertheless, while the concept has acquired strategic connotations, by stressing socio-economic processes, it has remained open to different interpretation influenced by political perceptions of Roma identity, migration as well as domestic policy approaches to integration. The pivotal instability in the discourse concerns the question of whether exclusion entitles an individual or a group to seek opportunities through migration and whether receiving countries are obliged to provide necessary support. Building on equality scholarship, this chapter argues that portrayal of Roma as "welfare migrants" who move across Europe exploiting generosity of welfare states, legitimizes hostile public interventions that negate official commitments to the Free Movement principle. The case of Wroclaw has received unprecedented political and media attention and demonstrates that anti-Gypsy discourse is used to mask unwillingness and inability of the state to design and implement coherent migration strategies, reflective of the European principles and recommendations. It also shows that "migration panic" is equally strong in the new EU members, largely unprepared to act as receiving countries.

\footnotetext{
J. Kostka $(\bowtie)$

Department of Sociology, University of Lancaster, Lancaster, United Kingdom

e-mail: j.kostka@lancaster.ac.uk
} 


\subsection{Introduction}

The anti-immigration rhetoric in the EU, traditionally directed at non-EU citizens, has shifted following the latest EU enlargements toward the rejection of European citizens, to whom the European treaties guarantee free movement around the continent. Particularly, migration of the largest European ethnic minority, the Roma, ${ }^{1}$ has been accompanied by inflamed media reports and populist discourse laden with explicitly racist sentiments. While the Roma people are some of the many million Europeans who in their search for work and better life move to another country, the national and local decision-makers do not perceive their migration as a natural occurrence within a united Europe but rather as a problem or a threat to sovereign stability. A study commissioned by the Organization for Security and Co-operation in Europe (OSCE) describes in detail the illegal surveillance of Roma migrants, forced evictions, and ethnic profiling by the police (Cahn and Guild 2010). According to the European Union Agency for Fundamental Rights (FRA) the criminalization of Roma migration has repeatedly served as an excuse to destroy Roma settlements as "cauldrons of criminality" and select EU citizens on the grounds of ethnicity to deport them (FRA 2009). Legally dubious practices of collective deportations of Roma have taken place in France, Italy, Sweden, and Belgium (Severance 2010; Parker 2012; O’Nions 2011; Fekete 2011).

While the origins of Romani westward migration date back to the 1990s (Sobotka 2003) the expansion of the EU in 2004 and 2007 deepened public insecurity and intolerance vis-à-vis Roma migrants (European Commission 2008). Politicized discourse of "waves", "flows" or "floods" of Roma people arriving in Western European countries effectively masks the fact that migrants act on personal decisions as to how best to improve their personal circumstances and realize the vision of a good life. The impact of media attention and right-wing rhetoric have resulted in the authorities presenting Roma migrants as "fraudulent" when they approach public authorities for legitimate entitlements, including social welfare assistance, access to employment opportunities, healthcare, and housing. Moreover, despite the fact that Roma are an extremely diverse minority group and their experiences in the course of inner-European migration differ widely (Kropp and Striethorst 2012) the media and politicians stubbornly construct an image of a homogeneous and deviant group, often labelled "benefit tourists". ${ }^{2}$

Whereas the situation and treatment of Roma migrants in the old Member States have received extensive analytical attention, migration of Roma across the new Member States continues to be overlooked. An intrinsic assumption that Roma migration is a solely westward phenomenon has diminished interest to undertake critical analysis of migration patterns and policies within countries such as the

\footnotetext{
${ }^{1}$ Today, more than ten million Roma live in Europe, with $75 \%$ residing in the EU. The Council of Europe provides an average estimate of Roma people in Europe of 11,166,500, with upper estimates of over 16,000,000 (Council of Europe 2012). A problematisation of these estimates is offered by Messing in this volume.

${ }^{2}$ Framing Roma migration in terms of "benefits tourism" is clear in headlines such as "The Gypsies who sparked a crackdown on benefit tourism" (Bentley, P. 2014).
} 
Czech Republic, Hungary, or Poland. Despite urgent calls coming from nongovernmental organizations (NGO) and activists about the intensifying violations of the human rights of Roma migrants (Móricz 2013; Nomada 2013, 2014) the international watchdog organizations have failed to recognize or reprimand practices undertaken by the Central and Eastern European (CEE) governments, even though they strongly resemble the oppressive measures employed in the West.

This chapter presents a case study of the situation and treatment of Romanian Roma migrants currently residing in Poland. It weaves together data collected through participatory observations undertaken by the author as part of consultancy work (2013-2014) with Nomada Association (a grassroots NGO actively working with the Romanian Roma community residing in Wroclaw) with activist materials, news reports, and policy briefs to expose and critically analyse existing policy interventions. The research demonstrates that a lack of integration policies and the portrayal of Romanian Roma migrants as "moral outcasts", unwilling to integrate and contribute to the society, legitimizes public interventions based on a particular form of social authoritarianism. In this hostile policy landscape, the focus shifts away from solidarity and social justice towards control, restrictions, surveillance, and expulsion. The chapter argues that not only are these policies ineffective, but they reinforce social stigma and force entire families into abject poverty and exclusion.

The chapter starts with an account of the changing migration patterns in Poland detailing the arrival of Roma migrants in the 1990s and the initial responses of the Polish state. It then examines the legal changes following the accession of Poland to EU and endorsement of the Freedom of Movement Directive. The last part analyses adopted interventions based on the particular form of social authoritarianism, showing their detrimental effect on social cohesion and integration.

\subsection{Changing Patterns of Migration and Policies in Poland}

For over a century, Poland has been one of the largest migrant-sending states in the CEE region and a vast reservoir of labour for many countries in Western Europe and North America. However, researchers have predicted that over the next decades Poland will gradually shift from being a major sending country to a country of transit migration and net immigration (Górny et al. 2009; Geddes and Scholten 2016). Poland as a full-fledged EU member with a relatively stable and growing economy (OECD 2016) provides vital economic opportunities for people from economically less developed countries in the region. Ukrainian migrants, in particular, tend to choose Poland as a destination country, a pattern dictated as much by economic need and political instability as by strong historical ties between these two countries (Okólski 2004). Nevertheless, despite the increase in overall immigration rates, in 2016, the foreign-born population living in Poland reached only 1.6\%, the lowest percentage in the EU (Eurostat 2016). According to the Office for Foreigners of the Polish Ministry of Interior, in 2014 there were 121,219 foreigners living in Poland legally (including registered EU nationals). There is no official data on the number of incoming or settled Roma migrants, and thus far the government has made no 
attempt to analyse the legal and socio-economic circumstances of this group. According to activist research conducted by the Western Centre for Social and Economic Research (ZOBSE) (Marcinkowski 2015) there are around 1500 people who identify as Romanian Roma and live in informal encampments located on the outskirts of large cities (including Warsaw, Wroclaw, Poznan, Cracow, and Gdansk). ${ }^{3}$ Given these small numbers, immigration scholars continue to argue that at this moment Poland (just like the Czech Republic, Hungary, and Romania) is mainly a transit country or a gateway to the West (Iglicka and Ziolek-Skrzypczak 2010). The transit thesis means that little research has been conducted on permanent or circular patterns of migration, apart from Polish repatriates. ${ }^{4}$ The notion of homogeneity within Polish society after WWII continues to be strict, resulting in an inability to see and discuss the changing dynamics of Polish demography.

In this landscape, it is perhaps not surprising that the presence of Roma migrants in Poland for years has not received political or academic attention. It is still common to talk about Roma migrants solely in the context of recent EU enlargement (Vlase and Preoteasa 2012). ${ }^{5}$ However, Roma migration across Europe commenced already in the 1990s, when Roma people from the Eastern European Bloc began to flee abject poverty and increasing levels of ethnic violence in their home countries (Bhabha et al. 2017). Although Poland often served as a one way stop towards the West (mainly for Roma from Romania, Bulgaria, and ex-Yugoslavia), many families (usually the most impoverished) stayed behind and settled in various parts of Poland. ${ }^{6}$ This effectively means that Romanian Roma migrants have been living in Poland for over 20 years, often in abject poverty, and exposed to daily harassment and discrimination. Activist research shows that children who were born in the Polish territory are often not recognized as rightful citizens or residents, and do not have access to basic education (Marcinkowski 2015). ${ }^{7}$ Many families lack valid identity documents, do not have basic health insurance and are not registered within the state's bureaucracy. They are forced to squat in makeshift houses without basic

\footnotetext{
${ }^{3}$ The research does not account for Roma migrants living outside of the informal encampments.

${ }^{4}$ In early 1990s Poland introduces special regulations for returning Poles, targeted at the diaspora from the former Soviet bloc. A Polish Charter of 2008 defined several categories of members of the Polish diaspora, which meant exemption from paying for entry visas and access to the labour market on an equal basis with Polish nationals (Kępinska and Kindler 2014).

${ }^{5}$ It is important to keep in mind that there are few studies on Roma migration in the CEE region. In 2017, the Social Identity: Journal for the Study of Race, Nation and Culture published a special issue "Un/Free mobility: Roma migrants in the European Union" (Yildiz and De Genova 2017) which placed the marginalisation of the Roma at the veritable centre not only of "minority" questions in racial and ethnic studies but also at the very heart of migration and mobility studies in the European context. However even in this important and timely contribution, focus on migrants in the new Member States remains limited.

${ }^{6}$ There is not data on the number of Roma migrants arriving in Poland in the 1990s and there are only anecdotal accounts on why some people decided to stay.

${ }^{7}$ For example, in the Romanian Roma community in Wroclaw living on the informal encampment on Kaminskiego Street (around 150 persons), nobody attended any form of education in Poland. The oldest residents, age 45-60 completed at least 3 grades of Romanian primary education. Between 2011 and 2013 none of the children age 6-16 were enrolled in school or any other form of education (Nomada 2014).
} 
amenities, living off panhandling and scrap-collection. It is not an overstatement that long-term Romanian Roma residents are living a stateless life, fully excluded from basic citizenship rights and access to the most essential public services. And yet, the dismal circumstances of this ethnic minority have gone fully unnoticed by international organizations (including the EU, European Roma Rights Centre, and OSCE), domestic human rights institutions, and NGOs. The violent and discriminatory treatment of Roma migrants by the Polish state throughout the 1990s has never been exposed or reprimanded, and now constitutes a part of "forgotten history", often denied by the authorities.

In the $1990 \mathrm{~s}$, Poland developed one of the most restrictive immigration policies in the region (Vermeersch 2005). This phenomenon was driven by the obligations of EU membership and coercive pressure to install new "hard" boarders on the Eastern and Southern frontier of the new Member States. The widely spread contention that most immigrants arriving in Poland are transit migrants on their way somewhere else triggered little political or public concerns. Outside the discourse on repatriations of Poles from the former Soviet Bloc few organizations and even fewer politicians engaged in discussions over integration, non-discrimination, and the need for far-fetched immigration policies. Not surprisingly Poland did not define integration in any legal document, often under the assumption that immigrants would automatically assimilate or would eventually leave the country (Iglicka and ZiolekSkrzypczak 2010).

In this legal context, official policy towards Roma migrants who overstayed their visa permits was that of eviction and "on-the-spot" deportation. The legality of these actions was neither monitored nor documented and currently there are no reliable records accounting for the exact number of deportations open to the public. ${ }^{8}$ According to the Ministry of Interior all deportations were executed in line with the Polish law of that time, ${ }^{9}$ however activist reports stress that they were rarely supported by court decisions and often entire communities were purposely misled about their basic rights (Nomada 2013; Marcinkowski and Rusakiewicz 2015). Perhaps the most violent and legally dubious deportation took place in Wroclaw in 1998. According to the news report (Gazenta Wyborcza 1998), on the 15th of October at 6am the riot police and border guards converged on the Romanian Roma informal encampment in Tarnogaj (district of Wroclaw). Around 100 people, including small children, were rounded up and forced on to buses, with no prior notice. In what was called Operacja Obcy (Operation Alien), the county police, in full riot gear and rubber gloves, began to demolish the settlement using iron bars and sledgehammers. The residents were transported to the border guard unit in Kłodzko, close to the border with the Czech Republic, where they were placed in a gymnasium, and

\footnotetext{
${ }^{8}$ There are many media reports of evictions and deportations that took place in large Polish cities; however, the government has never released an official report or statement to the public. This also applies to deportations of immigrants from ex-Soviet republics who tried to settle in Poland throughout the 1990s. Ministry of Interior refused to grant access to the archival documents to the author of this article.
}

${ }^{9}$ Phone conversation with Press Office of the Ministry of Foreign Affairs May 6, 2014. 
deported on the same day. In an interview, colonel Lech Surówka, a spokesman for the Commander of the Sudeten Border Guard, stated that the demolition of the settlement was done according to the protocol. When asked why such drastic measures were employed, he explained: "No point of leaving them here, the winter is coming, begging will stop and theft will begin" (Gazenta Wyborcza 1998). Similar operations took place in Poznan (1993 and 1999), Warsaw (1996 and 1998) and Cracow (1996) (Marcinkowski and Rusakiewicz 2015). According to a witness, the wellknown Polish anthropologist Jerzy Fickowski, many of these operations resembled roundups common during WWII: "It was disinfestation, not a normal way to treat people" (interview in Gazeta Wyborcza 1996).

Not surprisingly, a coping strategy adopted by many Romanian Roma families has been that of "invisibility", that is, the avoidance of all contact with the authorities and any form of institutionalized assistance. Roma families have found shelter in the most secluded places, often close to landfills or on post-industrial sites, ready to relocate at any moment, with interfamily networks serving as the only safety net. Papadopoulos et al. (2008) argued that becoming imperceptible is often the most effective tool that a marginal population can employ to oppose prevailing forms of state violence. Certainly, in the case of Romanian Roma, invisibility proved an effective strategy of evasion, as the topic of Roma migrants disappeared from public debates for more than a decade. Without clear legislative power over immigration, local authorities turned a blind eye to the growing destitution of "transit migrants" in the hope that sooner or later the unwelcomed guests would leave on their own. However, the strategy of evasion has been detrimental to the health and well-being of the entire Roma migrant community. Whole families became disconnected from any form of public assistance, and were exposed to dramatic levels of poverty. In all respects, the living conditions of Roma migrants fall drastically below accepted domestic and European standards. A life in makeshift huts constructed from hazardous material without vital amenities - no running water, garbage disposal, sewage system, and electricity - in constant fear of eviction and removal has generated an inter-generational trauma (Hohmann 2013).

The accession of Romania to the EU granted the Romanian Roma communities EU citizenship, which under the so-called Freedom of Movement Directive (2004/38/EC) protects them from violent deportations. However, this new-found status has proved of little benefit and paradoxically only further excludes Roma migrants from socio-economic life and access to public services.

\subsection{Policies and Narrative Towards Roma Migrants}

In 2004 Poland transposed the Freedom of Movement Directive of the European Parliament and of the Council of 29 April 2004 into domestic legislation. The Directive confers on every citizen of the Union a primary and individual right to move and reside freely within the territory of the Member States. However, while the freedom of movement opens the national economies to flows of capital and 
labour it drastically curtails the rights of "less desirable populations" to move around and settle in their place of choice. Article 12 introduces strict eligibility criteria for those who wish to register in the host country, these include proof of employment, self-employment, or financial self-sufficiency, and possession of valid health insurance. In Poland, the authorities apply a sufficient resources test to all registering citizens of the Union, and demand proof of permanent address ( $\$ 2$, Law Journal, No. 217, item 1616). The authorities automatically reject all those who do not meet the stipulated criteria, forcing people out of the system, and striping them from the right to access public services. While the directive talks about nondiscrimination (art. 20), social cohesion, and integration (art. 18, 19) it reserves free movement for active workers and wealthy elites who do not rely on social support. Article 16 articulates this bluntly by stating that it is possible to expel people who "become an unreasonable burden on the social assistance". In this manner, the Directive can be used to justify the lack of multifaceted integration programmes for EU citizens in Poland, as those who are "allowed" residency are deemed wellresourced and self-sufficient while those without sufficient resources are either pressured to leave or are fully ignored. ${ }^{10}$

Under these circumstances, the impoverished Romanian Roma communities found it almost impossible to register as EU citizens, often finding themselves in a limbo of bureaucratic protocol. ${ }^{11}$ Many individuals are also afraid to register, rightfully fearing prosecution, harassment, and expulsion (Marcinkowski and Rusakiewicz 2015). According to the Commissioner for Human Rights (2014), the government tends to simply ignore problematic cases (i.e. expired documents, lack of permanent address, precarious employment) hiding behind eligibility criteria and ignoring the dramatic socio-economic exclusion of long-term residents. Those who are willing to register cannot count on well-informed assistance, and their cases are often reviewed in an ad hoc manner, often dependent on the good will of individual agencies and/or bureaucrats. Moreover, while Poland transposed all the articles of the Directive 2004/38/EC, it did not systematize procedural protocol nor synthesize the EU requirements with the existing legal provisions and institutional modus operandi. The effect is one of confusion, procedural inconsistencies, and limited knowledge about the proper course of action. This is particularly acute at the lower tiers of government (Duszczyk and Lesińska 2009). These factors generate an evasive attitude among public administrators and frontline workers who are not always certain about their own decision-making discretion and are excessively constrained by byzantine protocol. In fact, it is still common for bureaucrats to label Romanian Roma as illegal immigrants excluding them from available programmes (i.e. registration as unemployed) and mobilizing interventions in full breach of EU Directives (Nomada 2013, 2014).

\footnotetext{
${ }^{10}$ See Nagy in this volume for an in-depth study on financial profiling of Roma in the UK.

${ }^{11}$ The situation is now slowly changing, due to tremendous efforts undertaken by local NGOs, and dedicated individuals who help Roma migrants during registry process. Local activists assure that without legal, financial, and culturally sensitive assistance, registration is virtually impossible, and cannot be completed successfully even by the most willing and determined individuals (Nomada 2014).
} 
Even in instances where Roma migrants do manage to register in the system, they cannot count on any quality social assistance. An economically deterministic interpretation of the Freedom of Movement Directive is based on the premise that EU citizens are economically self-sufficient and in no need of state's support. Hence, the Polish government does not prioritize integration of EU foreigners and has yet to pass proper legislation. The first timid step toward strategic thinking about integration took place in 2011, when the Working Group operating within the interministry Team for Migration presented a document titled The Polish Migration Policy: Its Current State and Further Actions (Ministry of Internal Affairs and Administration 2011). The strategy outlined the main lines of action around integration, however its scope was extremely limited, as it did not discuss issues such as access to public health care, education, and social housing. Paradoxically, the strategy was directed exclusively at those foreigners who "integrate easily into local communities" such as foreigners of Polish origin, foreigners from the East ${ }^{12}$ and international students (Duszczyk and Góra 2012). The explicit disregard for the presence and needs of impoverished and irregular migrants is a striking example of the revocation of the rights to residency (and in fact citizenship) for migrants believed to be "undeserving" or "culturally incompatible". As a matter of fact, the strategy bluntly stated that foreigners should not perceive integration programmes through the prism of the provision of social benefits (Ministry of Internal Affairs and Administration 2011: 70). Statistics on the use of social security instruments confirm that the share of foreigners is marginal (Duszczyk and Góra 2012). Thus, it is ironic that the current discourse presents poor migrants as welfare tourists, who live off social support and exploit the charity of "good Samaritans".

The explicit rejection of integration policy as a means to provide foreigners with adequate public assistance is further manifested in the way the Polish integration regime is institutionalized. Integration responsibilities are scattered across different State Ministries and Departments, who tend to work in silos and often neither have a clear mandate for action nor prioritize integration in their portfolios. While the Ministry of Labour and Social Policy handles integration programmes, it is the Minister of the Interior and Administration that is accountable for issues pertaining to visa policy, for granting the right to stay and for actions targeted at refugees. The analysis shows that no direct relationship between these two parts is stipulated by Polish legislation, hence immigration policy is fully disconnected and often incompatible with integration measures (Duszczyk and Góra 2012). Decisions made within migration policy do not entail any decisions concerning the integration policy or any changes in the foreigners' access to the social security system. This means that the opening of the Polish labour market to foreign workers is not accom-

\footnotetext{
${ }^{12}$ This geographical and cultural preference is clearly stipulated in the government strategy document on Poland's migration policy. In accordance with the priorities set out in Resolution No. 2 of the inter-ministerial Committee for Migration of 2007, geographic preference for the admission of third country nationals to the Polish labour market (the Eastern Neighbourhood Countries and the Caucasus Countries) are maintained.
} 
panied by decisions concerning their inclusion into Polish society. The migration policy doctrine assumes the primacy of labour market needs (i.e. replenishment of emerging labour force shortages) with full disregard of issues related to equality, social justice, and individual well-being. One wonders whether the government really has any interest in expanding integration policy or whether the urge not to accommodate migrants (at least those who do not have the desirable skills) in any way at all is a more dominant factor. In the case of Roma migrants, the state simply continues its politics of control and expulsion, so painfully executed throughout the 1990s, albeit now more constrained by Directive 2004/38/EC. The representation of Roma migrants as "delinquent" and unwilling to integrate legitimizes increasingly hostile and paternalistic approaches, based on control, surveillance, and eviction.

Over the past few years, Poland has seen extreme nationalistic movements and right-wing organisations and parties gain influence inside and outside the parliament. The recent "refugee crisis" has reinvigorated anti-immigration forces across the entire EU. In the case of Poland, it has created an opportunity for both populists and the mainstream right to build support using fear and xenophobia. The scapegoating of non-existent refugees has proven to be a very effective political tactic, with most of society having limited experience and knowledge on the subject, thus being unable to assess the veracity of the xenophobic messages. ${ }^{13}$ The coming to office of the ultra-right, populist government in $2015^{14}$ only intensified antiimmigrant rhetoric, now characterised by emotional narrative, which fully neglects facts and data (Hall and Mikulska-Jolles 2016). The media has played a key role in shaping negative popular opinion toward migration, describing the phenomenon with military allegories, comparing the inflow of refugees to natural disasters and diseases. The public debate on social media also experienced an outburst of xenophobia and blunt hate speech. The analysis conducted by the Centre for Social Opinion Survey (CBOS) in October 2015 shows that only 6\% of Polish internet users commenting on migration spoke out in favour of helping immigrants and of their integration. ${ }^{15}$

The intra-EU migration of Roma people added a new impetus to long-standing prejudices towards indigenous Roma communities. ${ }^{16}$ The prevailing attitudes portray Roma communities as a locus of uneducated, culturally backward, and lazy

\footnotetext{
${ }^{13}$ In a survey for International Organization for Migration, only $28 \%$ of Poles declared to have had contact with a foreigner in 2016.

${ }^{14}$ In October 2015, Poland has consolidated its right-wing shift after voters had handed an absolute majority in its parliamentary election to Law and Justice, a Eurosceptic party that is against immigration, wants family-focused welfare spending and partisan control over the rule of law.

${ }^{15}$ See Leggio in this volume on media narratives about "Roma migrants" in the UK during the Brexit campaign.

${ }^{16}$ Polish Roma Community in Poland consists of approximately 20,000 persons. Roma are divided into several groups: Polish Roma, Bergitka, Lovara, Kelderari, Sinti, Chaladytka (Russian) Roma. Persons of Romani origin experience discrimination, rejection, negligence as well as open hostility and aggression from average persons and representatives of various institutions (Polish Roma Association 2012). It is important to note that in public discourse Roma are constructed as a homogenous group, with little acknowledgement of sub-group divisions and nationality.
} 
people, predisposed to criminality and exploitation of social benefits and charity hand-outs. In recent years, the negative discourse has intensified with direct accusations of delinquency, aggressive panhandling, destruction of private property and disregard for Polish norms and customs. This portrayal is evident in media headlines, such as those published by the largest daily paper of Lower Silesia, for example: "Gypsies attack people in the old square", "Gypsies grope passing women. How to protect yourself", "Roma are not poor they know how to lie and steal" (Kozioł 2014). In an institutional setting (i.e. social assistance, education, health care) these negative attitudes are perhaps less overt; however Romanian Roma are stubbornly portrayed by frontline workers as quarrelsome, "unable to follow the rules", "culturally backward", "unable to take care of themselves and their children".

Not surprisingly, few politicians are willing to acknowledge that poverty and exclusion of Roma migrants stems from years of public harassment, unequal treatment, and institutionalized racism. Overall, Roma issues are separated from the general debates about systemic inequalities, legal deficiencies, and discriminatory treatment of foreigners. This conveniently creates an image of a group that is not willing to benefit from an array of well-functioning public services and procedures. Negative perception and stereotypes among frontline workers reinforce resistance to provide Roma families with adequate assistance. It is common to talk about Roma communities in terms of the "undeserving poor" who refuse to work, reject the middle-class model, and more importantly are a burden on the public purse. A blunt statement from a manager of a social work team in Wroclaw shows the dramatic lack of understanding of the real barriers to integration and functioning in the society: "They come and go, they don't want to work, or send their children to school, it is not possible to work with them, they lie but worst of all they force children to beg" (interview, Wroclaw 2013). Some frontline workers I interacted with went as far as to state that Roma prefer to live in poverty, and are unable to function as "normal people". The pervasive trend of seeking the cause of poverty and justification for policy failures in the community itself and its specific culture gives legitimacy to extremely conservative, morally charged, and penalizing interventions. Political rhetoric places Roma outside the domain of the social proper, and justifies morally charged policies aimed at helping or coercing Roma to become "fitting" citizens. While some localities rely on less coercive schemes than others, the effect is always the same - a gruesome violation of human rights, inconsistent application of Polish law, and systemic abjection of entire communities. It is important to mention that none of the measures implemented thus far, no matter how violent and oppressive, have managed to achieve the implicit - and sometimes explicit - goal of curbing Roma migration, or forcing long-term residents out. Instead oppressive measures traumatized entire families, stripping them of agency and all opportunities for socio-economic advancement or well-being. 


\subsection{The Flourishing Power of Social Authoritarianism}

The treatment of Romanian Roma fully exposes the grave shortcomings of Polish integration measures but also the conservative and penalizing nature of social assistance programmes. In many situations, social workers as well as community development practitioners and integration experts appear complicit in implementing social policies that are degrading and inhumane. Interventions are dispatched in an ad hoc manner, usually as a reaction to publicized "crisis" i.e. inflammatory media reports, epidemic scares, and official complaints. They also have a schizophrenic character, on one hand basic humanitarian aid is delivered (e.g. providing blankets, water tanks, and portable toilets) and on the other hostile security measures are normalized (e.g. surveillance, control checks, eviction, removal of children). This is best illustrated in the city of Wroclaw, where after agreeing to provide the informal encampment on Kaminskiego Street with portable toilets, garbage disposal units and water tanks, the authorities unleashed an array of intimidation tactic, including unscheduled controls by the City Guard and police, random public health inspections and early morning visits by social workers. According to the Roma residents, visitors always demanded detailed information about the families, conducted illegal searches of the houses, and insisted that a failure to comply with their instructions, could result in children being removed (Nomada 2014). These kinds of actions and threats are extremely common, and are used to exert pressure of the most painful kind as a social lever to secure acquiescence.

Direct harassment is complemented with morally charged anti-poverty campaigns usually aimed at changing the "problematic behaviour of impoverished groups" rather than promoting wider structural adjustments and reforms. One such oppressive strategy, mobilized under the auspices of eradicating anti-social behaviour, is stigmatization and penalization of street begging. ${ }^{17}$ Abject poverty and systemic discrimination has forced many Roma families into mendicancy, which now constitutes the main source of income for entire communities. In a strict sense mendicancy is not illegal in Poland - the regulation prohibits the aggressive and fraudulent extortion of money, and begging performed by minors ${ }^{18}$ - however it lends itself to public outcries driven by an omnipresent stereotype of a "begging gypsy", too lazy to do anything else, and flamboyant tabloid stories of tremendous wealth accumulated by begging Roma. ${ }^{19}$

Anti-begging campaigns appeared in 2011, as a means of tackling the alleged problem of "aggressive begging" and to discourage members of the public from

\footnotetext{
${ }^{17}$ See Raithelhuber and Ravnbøl in this volume on the governance and practice of begging among Romanian Roma in Austria and Denmark.

${ }^{18}$ Code of Administrative Offences, Article 58.

${ }^{19}$ In 2013 popular internet portal trojmiasto.pl published a story about Romanian Roma beggars in the city of Gdansk under the title Gdansk attracts beggars, they 'earn' thousands of zloty per day. In an interview, a manager of social work unit Monika Ostrowska insisted: "They [Roma] are very clever and have developed methods of begging to perfection. Recently, children begged with a small dog. It arouses pity. Please do not be fooled by their poverty".
} 
giving money to beggars (Fertsch and Roik 2011). Publicly funded posters, brochures, and fliers circulated in Polish cities with slogans such as: "Don't Give Money on the Street", "Help for Real", "Begging is a choice not a necessity". While local councils maintained that the deliberately "hard-hitting" campaign was not anti-Roma, they admitted that lack of street donations will force the Roma people, as well as the homeless, to relocate. As stated by the MP representing the city Bydgoszcz: "If we cut them off they will have to leave" (Phone Interview, Bydgoszcz 2017). The campaigns are often reinforced by control checks, issuing of fines, and confiscation of money. Whist under the Polish Petty Offenses Act (Penal Code) a person can only be fined if she or he is able to work or has enough resources to live independently, the law does not provide a definition of the level of resources deemed to be "enough to live independently" nor of an "importunate or fraudulent manner". The police are therefore able to decide at their discretion whether to charge someone with an offense, or simply ask the person to leave the area. Far from being effective, the campaigns reinforce social stigma by implying that beggars are engaged in criminal activities, and that they have other choices for generating income. It is not coincidental that instances of verbal abuse and harassment of Romanian Roma increased shortly after the campaigns took to the streets. As a mother of three children confessed: "It was always bad, but now it is very very bad, people spit on you, and call you names, but I need to sit, I need to buy food for my children" (Interview, Poznan 2014).

Stigmatisation of begging corresponded with measures that interdicted squatting, rough sleeping, and homelessness, even though homelessness is not subject to penalty in Poland (Browarczyk 2013). Due to extreme levels of poverty, rampant discrimination in the housing market, and shortage of social housing, the majority of Romanian Roma live in informal encampments often located on vacant public land. The mainstream public discourse labelled these communities illegal ghettos that breed a parasitical dysfunctional underclass of failed human beings. Such framing justifies hostile interventions aimed at the removal of Roma families from their place of residence, often without a clear legal mandate and no alternative housing provided. By clearing the city of undesirable elements, the authorities force Romanian Roma to subsist in often degraded abject border zones within the state. The families not only lose all their belongings but also filial networks of friendship, care and protection. Their faith and trust in the state and state actors, already very fragile, is tarnished completely.

More recently, after the abovementioned violent eviction of 1998, the most wellknown legal intervention against Roma from Romania took place in the city Wroclaw in 2012, when the Mayor's Office pronounced the encampment on Kamienskiego Street as illegal, dangerous, and a risk to public health - opinion issued by the Sanitary Inspectorate prior to any investigation. On the 19th of March 2012, the City tried to demolish the camp and remove its residents with the help of the municipal police. The authorities eventually abandoned the action due to an unclear legal mandate and conflict about who should bear responsibility for the eviction. Although the incident showed that municipalities are not in possession of legal policy tools to address informal housing, it did not prevent the City Hall from 
conceiving alternative ways of eradicating the encampment (Nomada 2014). On the 26th of March 2013, the residents from the Kamienskiego Street received an official notice to vacate the premises within 2 weeks. On the 18th of April 2013, the city filed a lawsuit for the eviction of 47 adults and children in the District Court in Wroclaw.

Civil society organizations, including Amnesty International, named the court proceedings a striking example of structural discrimination and legal incompetency in breach of the Convention for the Protection of Human Rights and Fundamental Freedoms, the Covenant on Civil and Political Rights and the Constitution of the Republic of Poland. The defendants were neither provided with adequate translation services ${ }^{20}$ nor legal assistance (Nomada 2014). In January 2014, the Polish Society of Anti-Discrimination Law and the Commissioner for Human Rights appealed to the Mayor of Wroclaw to withdraw the case and commence a mediation process with the defendants. However, neither the appeals nor the realization that the lawsuit would not resolve the situation, ${ }^{21}$ resulted in the suspension of legal proceedings. Following three hearings the case was adjourned and presently there is no available information about further proceedings.

The case of the Kamienskiego camp, widely covered by the media, set in motion a series of evictions and legal prosecutions across Poland. In 2013 a Roma family living in Poznan was evicted from an abandoned building, under the decision of the County Inspectorate of Construction which deemed the dwelling unsafe. ${ }^{22}$ Yet the family (with children under five) was not provided with alternative housing (required by the Polish law) or any form of social assistance. The authorities insisted that the family was given an option to move into a homeless shelter, but refused. Given that shelters in Poland are segregated by gender it should not be surprising that the family refused to live there, instead relocating to another informal camp located on an abandoned allotment.

In 2014, local authorities in Gdansk allowed for a demolition of a 3-year-old encampment in Jelitkowo, without providing legal notice (required by the Polish law) and without the knowledge of the Municipal Family Support Centre. Under the pressure from human rights activists the Vice Mayor of Gdansk admitted that the demolition took place "a bit too early", due to a break in communication channels among the City Hall, the City Guard, and the Social Services. Even though 30 people (including children) lost all their possessions and became homeless, the decision was not condemned by the Prosecutor's Office and no alternative housing was provided. Similarly, in 2015 a small camp on Paprotna Street in Wroclaw, a home of an

\footnotetext{
${ }^{20}$ The court provided only Romanian translators without taking under consideration that the defendants speak a Romani dialect. Despite the appeals by civil society organizations the court has refused to grant permission to bring in a Romani translator.

${ }^{21}$ It is important to mention that there are close to 150 people residing in the settlement, hence the lawsuit does not affect all residents.

${ }^{22}$ The request for public disclosure of the assessment report, delivered to the authorities by the County Inspectorate of Construction, was denied (last request was made by the author on the 5th of July 2017).
} 
extended Roma family, was "cleaned" and "cleared" by the workers of the City Guard and Urban Greenery Unit. When questioned by activists about the decision, the Mayor's Office insisted that the warrant for clearing was issued by the District Inspectorate, an autonomous public agency, hence circumventing legal responsibility. In a meeting with the Nomada team, the legal advisor of the Mayor's Office insisted that the area was "unoccupied". This is a blunt fabrication as the camp has been under continued police surveillance and the municipal social work unit regularly visited its residents. Less publicized evictions took place in Warsaw and Cracow, where entire families were evicted from vacant abodes, once again without any assistance provided.

According to the Polish law, local authorities are required to provide shelter and support to homeless people and people who are evicted (Journal of Laws of 15 April 2004, No. 64, item 593). However, this assistance is often based on behaviour control, which gives officials and care workers complete power over the "clients". For example, in 2014 the Municipal Social Work Unit moved a Romanian Roma family from the encampment on Kaminskiego Street to a social centre, under its authority. The centre subjected the family to daily controls (including room searches), 24-h monitoring, evening curfew and limited visitation rights. The social workers also endorsed a no tolerance for begging policy, which meant that any instance of noncompliance would result in immediate expulsion. Although the family was provided with food and basic personal items (i.e. sanitary products) it did not receive any financial allowance, as it was deemed that Roma would spend the money on "cigarettes" and "junk food". In meetings with local NGOs, social workers insisted that such control measures were necessary to "prepare and teach Roma how to lead a proper life". In effect, the assistance stripped the family of the ability to act, prevented them from influencing their own lives, and assuming responsibility for their behaviour. Human rights advocates compared the centre to a corrective institution, which not only hides poverty from the public view but also contributes to the further stigmatization and disenfranchisement of people.

\subsection{Conclusion}

The discrimination against Roma migrants living in Poland is still a severely underreported reality. This chapter conveys that for two decades the Polish state has endorsed an array of oppressive and violent approaches, which pushed Roma migrants into abject poverty and destitution. In many ways, the hostility towards Roma feeds on the fact that policymakers lack proper tools to respond to the arrival of impoverished families, now legitimate EU citizens. Paradoxically, the transposition of the Freedom of Movement Directive contributed to further exclusion and stigmatization of Roma migrants who have been living in Poland for more than a decade. The continuing disenfranchisement of this group shows that European citizenship does not by any means make the EU a fully inclusive society of equal citizens. In fact, the very design of the Directive unjustifiably disadvantages the poorest 
migrants, as it allows Member States to discriminate against economically inactive Union citizens labelled as an "unreasonable burden on the social assistance" (2004/38/EC: art. 14). In its current form, free movement within the EU provides unprecedented opportunities for 500 million citizens to live in each other's countries, but it is tied to a violent and oppressive system of exclusion. The differential treatment has allowed right-wing government of Poland to make the cynical, opportunistic argument for reconsideration of the benefits of the principle of free movement and roll out punitive interventions based on a particular form of social authoritarianism.

However, the dismal Polish response to integration challenges must be considered within the broader trend of welfare state retrenchment, punitive revamping of public policies and rebranding of poverty as personal failure. Omnipresent austerity measures have pushed millions of EU citizens into poverty contributing to growing tensions around access to jobs and welfare. Not surprisingly, the populist right-wing discourse eagerly frames migrants as a liability to countries that are already struggling with the effects of economic crisis. In many ways, the portrayal of Roma migrants as a deviant group incapable of living "a normal life" has intensified in tandem with a growing insecurity of Polish citizens, struggling with economic hardships. The emergence of explicit xenophobic movements (i.e. All Polish Youth) allows for drawing a distinction between "us" and "them" along lines of nationality and contesting the very question of who "belongs" in Poland as a full subject entitled to rights and protections.

In this context, political decisions have a central role in determining what Polish society will look like over the next few decades, how inclusive it will be, and whose economic, social, and political rights will be taken into account. The fact that Poland is still not receiving a high volume of immigrants should prompt the authorities to use this "quiet" time to devise policies and to experiment with novel approaches. However, at the moment the picture looks grim. The criminalisation of begging and squatting is tantamount to criminalising poverty. It perpetuates, rather than alleviates, the marginalisation and disadvantage experienced by impoverished communities. It also violates the fundamental human rights of some of the most marginalized people in Europe. Begging bans however, are the tip of an ugly iceberg of a wide base of antisocial behaviour measures. These measures are used to punish people in the name of maintaining public order. What we have here is essentially an attempt to criminalize the use of public space by all people considered "undesirable" by policymakers and corporate elites. As the European Commissioner for Human Rights, Nils Muižniek (2015) has said: "The criminalization of poverty hides problems from public view and undermines efforts to improve the living conditions of Roma who are stigmatized and discriminated against". While antagonism in some Polish cities is beginning to thaw, mostly because of grassroots advocacy, there is still no conception of how to alter and/or adjust policies and procedures to promote a sustainable, legitimate and accountable integration process. This will continue long-term unless we ensure that public spaces, public infrastructure, and social assistance, is accessible to everyone - including impoverished migrants. 


\section{Bibliography}

Benedik, S. (2010). On the streets and in the bed: Gendered and sexualised narratives in popular perceptions of Romani migrations within Central and Eastern Europe. Paper presented at the International Conference - Romani Mobilities in Europe: Multidisciplinary Perspectives, January 14-15, Oxford.

Bentley, P. (2014). The Roma gypsy who sparked a crackdown on benefittourism. Daily Mail, 15 November, http://www.dailymail.co.uk/news/article-2835442/The-Roma-gipsysparkedcrackdown-benefit-tourism-Elisabeta-Dano-25-tracked-German-city-finding-centrelandmark-welfare-case.html. Accessed 20 June 2017.

Bhabha, J., Mirga, A., \& Matache, M. (Eds.). (2017). Realizing Roma rights. Philadelphia: University of Pennsylvania Press.

Browarczyk, Ł., Dębski, M., Kwaśnik, A., \& Weiner, K. (2013). Forum about homelessness without fear [Forum o bezdomności bez lęku]. Gdańsk: Pomorskie Forum na rzecz Wychodzenia z Bezdomności.

Butler, E., \& Cashman, L. (2010). Romani mobilities in the context of the new EU: What could or should the EU be doing? Paper presented at the International Conference - Romani Mobilities in Europe: Multidisciplinary Perspectives, January 14-15, Oxford.

Cahn, C., \& Guild, E. (2010). Recent migration of Roma in Europe. Warsaw: Organization for Security and Co-operation in Europe.

Centre for Social Opinion Survey [Centrum Badania Opini Społecznej]. (2015). Attitudes of Poles towards refugees [Polacy wobec problemu uchodźstwa] Warsaw, June 2015, http://www.cbos. pl/SPISKOM.POL/2015/K_081_15.PDF. Accessed 20 July 2017.

Commissioner for Human Rights. (2014). The situation of Roma people in Wroclaw [Sytuacja Romów we Wrocławiu]. https://www.rpo.gov.pl/pl/content/sytuacja-rom\%C3\%B3w-wewroc\%C5\%82awiu. Accessed 20 July 21.

Council of Europe. (2012). Human rights of Roma and travellers in Europe. Strasbourg: Council of Europe Publishing.

Duszczyk, M., \& Lesińska, M. (Eds.). (2009). Contemporary migration: European and Polish Dilemas [Współczesne Migracje: Dylematy Europy i Polski]. Warsaw: Ośrodek Badań nad Migracjami.

Duszczyk, M., \& Góra, M. (2012). Active inclusion of immigrants in Poland. Iza Discussion Paper Series, 6427(3), 3-36.

European Commission. (2008). Discrimination in the EU: Perceptions, experiences and attitudes. Special Eurobarometer 296. http://ec.europa.eu/public_opinion/archives/ebs/ebs_296_en.pdf. Accessed 20 June 2017.

European Union Agency for Fundamental Rights. (2009). The situation of Roma EU citizens moving to and settling in other EU Member-States. http://fra.europa.eu/en/publication/2010/situation-roma-eu-citizens-moving-and-settling-other-eu-member-states. Accessed 20 June 2017.

Eurostat. (2016). Key figures on Europe. Luxembourg: Publications Office of the European Union.

Fekete, L. (2011). Accelerated removals: The human cost of EU deportation policies. Race and Class, 52(4), 89-97.

Fertsch, K., \& Roik, M. (2011). Anti-begging campaign in Poznan [Kampania przeciwko żebractwu w Poznaniu] Wiadomości Nasze Miasto. http://poznan.naszemiasto.pl/artykul/kampania-przeciw-zebractwu-w-poznaniu,985619,art,t,id,tm.html. Accessed 20 July 2017.

Gazenta Wyborcza. (1998). The alien: An invasion of the Romanian Roma Camp. Nr. 243. 16/10/1998.

Gazeta Wyborcza. (1996). Was the liquidation of the Romanian Roma Camp Necessary? Nr.143. 21/06/1996.

Geddes, A., \& Scholten, P. (2016). The politics of migration and immigration in Europe (2nd ed.). London: Sage Publications Ltd. 
Górny, A., Grabowska-Lusińska, I., Lesińska, M., Okólski, M. (2009). Poland becoming a country of sustained immigration (IDEA Working Paper). http://www.idea6fp.uw.edu.pl/pliki/WP10_ Poland.pdf. Accessed 20 July 2017.

Hall, D., \& Mikulska-Jolles, A. (2016). Prejudice, fear or lack of knowledge? Young poles talk about reasons for their negative attitudes towards refugees [Strach czy niewiedza? młodzi Polacy o powodach niechęci do przyjmowania uchodźców]. Warsaw: Stowarzyszenie Interwencji Prawnej.

Hohmann, J. (2013). Right to housing: Law, concepts, possibilities. Oxford: Hart Publishing.

Iglicka, K., \& Ziolek-Skrzypczak, M. (2010). EU membership highlights Poland's migration challenges. Migration Information Source. http://www.migrationpolicy.org/article/eu-membership-highlights-polands-migration-challenges. Accessed 20 July 2017.

International Organization for Migration. (2016). Survey on the attitudes towards foreigners in Poland [Badanie na temat postaw wobec cudzoziemców w Polsce] Warsaw: Office for Foreign Affairs.

Kępinska, E., \& Kindler, M. (2014). Poland. In A. Triandafyllidou \& R. Gropas (Eds.), European immigration: A source book (pp. 273-286). Farnham: Ashgate.

Kozioł, M. (2014). They steal, hassle, destroy and are not poor. How daily paper harasses Roma [Kradną, obłapiają, niszczą i nie są biedni. Jak "Gazeta Wrocławska" szczuje na Romów] Gazeta Wyborcza. http://wyborcza.pl/1,76842,16280560,Kradna_oblapiaja_niszcza_i_nie_ sa_biedni_Jak_Gazeta.html?disableRedirects=true. Accessed 20 July 2017.

Kropp, M., \& Striethorst, A. (2012). The migrations of Roma in the European Union - an ethnic minority as the sport of European politics. Transform: European Network for Alternative Thinking and Political Dialogue. http://www.transform-network.net/yearbook/journal-102012/ news/detail/Journal/the-migrations-of-roma-in-the-european-union-an-ethnic-minority-as-thesport-of-european-politic.html. Accessed 20 July 2017.

Marcinkowski, T. (2015). In their own voice: Romani immigrants in Poland [Własnym głosem o sobie: imigranci romscy w Polsce]. Gorzów Wielkopolski: Western Centre for Social and Economic Research.

Marcinkowski, T., \& Rusakiewicz, M. (2015). The context of Roma migration [Migracje romskie i ich uwarunkowania]. In T. Marcinkowski (Ed.), In their own voice: Romani immigrants in Poland [Własnym głosem o sobie: imigranci romscy w Polsce] (pp. 11-48). Gorzów Wielkopolski: Western Centre for Social and Economic Research.

Ministry of Internal Affairs and Administration. (2011). The Polish Migration Policy - It's current stare and further actions [Polityka Migracyjna Polski - stan obecny I postulowane działania]. Warsaw: Department of Migration Policy.

Móricz, I. (2013). An overview of the migration policies and trends - Hungary. http://migrationtothecentre.migraceonline.cz/en/an-overview-of-the-migration-policies-and-trends-hungary. Accessed 20 July 2017.

Muižniek, N. (2015). Recognise legal capacity of all people with disabilities. Council of Europe. http://www.coe.int/en/web/commissioner/-/recognise-legal-capacity-of-all-people-with-disabilities. Accessed 20 July 2017.

Mulder, C. H., \& Lauster, N. T. (2010). Housing and family: An introduction. Housing Studies, 25(4), 433-440.

Nomada Association for Multicultural Society Integration. (2014). Systemic exclusion and pathways to integration: The situation of the Romanian Roma living in Wroclaw. http://nomada. info.pl/publikacje. Accessed 20 June 2017.

Nomada Association for Multicultural Society Integration. (2014). Systemic exclusion and pathways to integration: The situation of the Romanian Roma living in Wroclaw. http://nomada. info.pl/publikacje. Accessed 20 July 2017.

O'Nions, H. (2011). Roma expulsions and discrimination: The elephant in Brussels. European Journal of Migration and Law, 13(4), 361-388.

OECD. (2016). Economic survey of Poland. http://www.oecd.org/eco/surveys/economic-surveypoland.htm. Accessed 20 July 2017. 
Okólski, M. (2004). Migration patterns in Central and Eastern Europe on the eve of the European Union expansion: An overview. In A. Górny \& P. Ruspini (Eds.), Migration in the New Europe (pp. 23-47). Hampshire: Palgrave Macmillian.

Papadopoulos, D., Stephenson, N., \& Tsianos, V. (2008). Escape routes: Control and subversion in the 21st century. London: Pluto Press.

Parker, O. (2012). Roma and the politics of EU citizenship in France: Everyday security and resistance. Journal of Common Market Studies, 50(3), 475-491.

Polish Roma Association [Związek Romów Polskich]. (2012). The report on the situation of Roma community in Poland. Available at: http://www.romowie.com/the_report.pdf. Accessed 04 Jan 2019.

Severance, K. (2010). France's expulsion of Roma migrants: A test case for Europe. Migration Policy Institute. http://www.migrationpolicy.org/article/frances-expulsion-roma-migrants-testcase-europe. Accessed 20 July 2017.

Sigona, N., \& Trehan, N. (Eds.). (2009). Romani politics in contemporary Europe: Poverty, ethnic mobilization, and the neoliberal order. London: Palgrave Macmillan.

Slavkova, M. (2010). Romani migrations from Bulgaria to Spain: Challenges and perspectives. Paper presented at the International Conference - Romani Mobilities in Europe: Multidisciplinary Perspectives, January 14-15, Oxford.

Sobotka, E. (2003). Romani migration in the 1990s: Perspectives on dynamic, interpretation and policy. Romani Studies, 5(2), 1528-0478.

Vermeersch, P. (2005). EU enlargement and immigration policy in Poland and Slovakia. Communist and Post-Communist Studies, 38, 71-88.

Vlase, I., \& Preoteasa. (2012). Roma migrants from Bulgaria and Romania. Migration patterns and integration in Italy and Spain 2011. In D. Tarnovski (Ed.), Roma from Romania, Bulgaria, Italy and Spain between social inclusion and migration. Bucharest: Soros.

Yildiz, C., \& De Genova, N. (2017). Un/free mobility: Roma migrants in the European Union. Social Identities. Journal for the Study of Race, Nation and Culture. https://doi.org/10.1080/1 3504630.2017 .1335819 .

Open Access This chapter is licensed under the terms of the Creative Commons Attribution 4.0 International License (http://creativecommons.org/licenses/by/4.0/), which permits use, sharing, adaptation, distribution and reproduction in any medium or format, as long as you give appropriate credit to the original author(s) and the source, provide a link to the Creative Commons licence and indicate if changes were made.

The images or other third party material in this chapter are included in the chapter's Creative Commons licence, unless indicated otherwise in a credit line to the material. If material is not included in the chapter's Creative Commons licence and your intended use is not permitted by statutory regulation or exceeds the permitted use, you will need to obtain permission directly from the copyright holder.

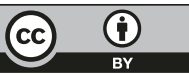

